\title{
Awareness of Forensic Odontology among Dental Students, Academicians, and Dental Practitioners in Gujarat: A Questionnaire Based, Cross Sectional Study
}

\author{
Jayasankar P. Pillai i", Sonam Rambia ${ }^{2}$, Thamarai Selvan \\ Chokkalingam $^{3}$ and Balamurugan Asaithambi ${ }^{4}$ \\ 'Department of Oral Pathology, Government Dental College and Hospital, \\ Ahmedabad - 380 016, Gujarat, India; jppillaigdch@gmail.com \\ ${ }^{2}$ School of Dentistry, UCLA, Los Angeles, USA; sonamrambhia111@gmail.com \\ ${ }^{3}$ Department of Forensic Odontology, Maulana Azad Institute of Dental Sciences, \\ New Delhi - 110002, India; inboxofthamarai@gmail.com \\ ${ }^{4}$ Chief Dentist and Forensic Odontologist, Nanthini Dental Care, Thanjavur, \\ Tamil Nadu, India; balaasainandhini@gmail.com
}

\begin{abstract}
Aim: This survey aimed to evaluate the awareness of forensic odontology (FO) subject among dental students, dental academicians (DAs), and dental practitioners (DPs) in Gujarat state. Materials and Methods: A questionnaire sheet containing 14 questions was answered by 607 participants consisting of dental students, DAs, and DPs in Gujarat. Descriptive statistics were used to summarize the responses, and the results were presented as frequencies and percentages. The Chi-square test was used to compare the responses among the groups, and the level of significance was set at $P<0.05$. Results: A total of 607 participants answered the questionnaire form. Out of 212 UG students, 175 (82.5\%) were aware of the FO branch and 181 (85.4\%) agreed to FO as a promising field in dentistry. The majority of the undergraduate (UG) students agreed that FO should be taught as a separate subject at UG and postgraduate level. The majority of the participants $(95.7 \%)$ agreed that dental evidence plays an important role in forensic cases. Nearly $80 \%$ of the respondents agreed for a separate PG course in FO and around 37\% of them opted for MDS course in FO. Bitemark analysis and dental age estimations were considered the promising domains in FO by $>80 \%$ of the participants. Conclusion: This questionnaire study was performed to analyze the awareness of FO among dental students, DPs, and DAs. The majority of the study participants were aware of FO. A thorough review of the literature on a similar topic was also done.
\end{abstract}

Keywords: Awareness, Dental Academicians, Dental Practitioners, Dental Students, Forensic Odontology, Questionnaire Article chronicle: Date of Submission: 09.04.2019; Date of Acceptance: 21.08.2019; Date of Publication: 24.04.2020

\section{Introduction}

The subject of forensic odontology (FO) is making stride to emerge as one of the major branches of forensic sciences and as a new speciality branch in dentistry. The Federation Dentaire Internationale defines FO as that branch of dentistry, in the interest of justice, deals with the proper handling and examination of dental evidence, and with the proper evaluation and presentation of dental findings. ${ }^{1}$ With the increase in the number of dental surgeons passing out every year, there is a need to expand the opportunities within the field of dentistry in addition

${ }^{*}$ Author for correspondence 
to the existing clinical postgraduate (PG) courses. Over the last few years, the subject of FO is evolving as a new branch of dentistry as evident through the number of courses and institutes in India imparting the knowledge of this special branch. Forensic odontologists or dental professionals are also approached by the legal and the forensic medicine authorities to give expert opinions as and when the need arises in several forensic cases. However, there is still a lacunae of recognized training or course on FO for dental surgeons to enhance their skill, confidence, and courage to face forensic cases in their day-to-day practice. Whenever a dental surgeon is used as an expert in the court of law, having trained and/ or certified in FO make their testimony more reliable. However, until today, there is no "recognized" master degree course for FO in India. Hence, dental surgeons who aspire to study FO seek admissions in some foreign universities, which unfortunately are not recognized in India. To pass the eligibility criteria, the course duration of such courses needs to be on par with the PG and/ or PG diploma course durations offered by recognized dental institutions in India. However, most of the foreign universities offer the master course for $\mathrm{FO}$ for the duration of 1 or 2 years. Currently, in India, dental students are given an introduction to $\mathrm{FO}$ at the undergraduate (UG) level in the subjects of oral pathology and oral medicine. There is no separate subject or paper in FO at the UG curriculum and a separate branch for FO in the MDS or PG diploma curriculum under the Dental Council of India (DCI). In future, if FO evolves itself as a new specialized branch in dentistry, it may provide a new ray of hope for the budding dental surgeons in India. However, some universities and institutions across India are offering formal training in $\mathrm{FO}^{2,3}$ A systematic review of published studies evaluating the knowledge, awareness, attitude, and practice of FO among several stakeholders such as dental professionals, medical and dental students, legal professionals, and police workforce in India was done. ${ }^{4-26}$ Most of the studies were conducted individually on single group, for example on dental students or dental practitioners (DPs), and only a few studies compared the responses between a diverse group of participants. With this background, a questionnaire survey was designed to include dental students, dental academicians (DAs), and DPs to evaluate their response and also to compare the responses among the groups in the state of Gujarat. The questionnaire in this survey addressed some of the academic and practical issues related to FO. Only the willing participants with signed consents were included in this study, and confidentiality was maintained.

\section{Materials and Methods}

\section{Study Design and Participants}

A cross-sectional questionnaire study was designed. Printed questionnaire forms were distributed to 650 individuals, and data of only 607 individuals who signed the consent form and answered all the questions in the survey were considered for analysis. The participants were grouped as:

- Group 1: Dental Under-graduates

- Group 2: Dental Post-graduates

- Group 3: Dental interns

- Group 4: DPs

- Group 5: DAs

- Group 6: DAs in dental practice (DADP).

\section{Questionnaire Design and Data Collection}

The questionnaire form consisted of 14 questions. The first question was related to the current professional position of the respondents and the remaining 13 questions were related to the knowledge and awareness in academic, clinical, and practical aspects of FO. There were 11 questions (Q. Nos. 2-7 and 9-13) with only "Yes" and "No" as options, whereas Q. nos. 8 and 14 had four options to choose. The questionnaire sheet along with the consent form was printed in the English language and was distributed to the respondents personally by the first two authors. The respondents answered the questionnaires without any external influence and returned the sheet to the authors on the same day.

\section{Statistical Analysis Used}

The data collected were entered in an MS office Excel spreadsheet (Office 2011, Microsoft Corp., Redmond, USA) and statistically analyzed using Statistical Package for Social Sciences (SPSS), Version 16.0 (SPSS Inc., Chicago, IL, USA). Descriptive statistics were used to summarize the samples and the responses of the participants. The association between different categories of participants was analyzed using a Chi-square test with $P<0.05$ as statistically significant. 


\section{Results}

Six hundred and seven out of the 650 participants willingly participated in this study by answering all the questions and signed the consent form. The response rate in this survey was $93.4 \%$. The distribution of the groups of respondents is depicted in the pie chart [Figure 1].

Response to Q. nos. 2-7 and Q. Nos. 9-13 was with "Yes" and "No" options.

The tabulation of the responses in the excel sheet revealed $63 \%$ of the overall affirmative response from the respondents for the 11 questions with "Yes" and "No" as options [Figures 2 and 3]. The respondents in Group 6 (DADP) answered the maximum number of affirmative answers (76\%) followed by those in Group 5 (DA) (71\%). The least number of affirmative responses was in Group 1 (UG students) (56\%). Out of the 607 respondents, 95.7\% answered "Yes"/"Agree" to Q. no. 4 and $<50 \%$ of the respondents answered "Yes" to Q. nos. 5, 9, 10, 11, and 12. Only $44.2 \%$ and $35.4 \%$ of the respondents were aware of the Indian Association of FO (IAFO) and Journal of Forensic Dental Sciences (JFDS), respectively. Nearly 64\% of the respondents were unaware of any forensic cases solved using dental evidence (Q. no. 5) and also were not

Table 1. The distribution of the participants' responses to the Q. nos. 2-7 in the questionnaire

\begin{tabular}{|c|c|c|c|c|c|c|c|c|c|c|c|}
\hline \multirow{3}{*}{$\begin{array}{l}\text { Question } \\
\text { number }\end{array}$} & \multirow{3}{*}{\multicolumn{3}{|c|}{ Subject of the question }} & \multicolumn{8}{|c|}{ Participants' response to Q. nos. 2-7 } \\
\hline & & & & \multicolumn{2}{|c|}{$\begin{array}{l}\text { UG students } \\
\qquad(n=212)\end{array}$} & \multicolumn{2}{|c|}{$\begin{array}{l}\text { PG students } \\
\quad(n=86)\end{array}$} & \multicolumn{2}{|c|}{ Interns $(n=167)$} & \multicolumn{2}{|c|}{ DPs $(n=50)$} \\
\hline & & & & Yes $(\%)$ & $\begin{array}{l}\text { No } \\
(\%)\end{array}$ & $\begin{array}{l}\text { Yes } \\
(\%)\end{array}$ & No $(\%)$ & Yes $(\%)$ & No $(\%)$ & Yes $(\%)$ & $\begin{array}{l}\text { No } \\
(\%)\end{array}$ \\
\hline Q.2 & \multicolumn{3}{|c|}{$\begin{array}{l}\text { Knowledge about the branch of } \\
\text { forensic odontology? }\end{array}$} & $\begin{array}{c}175 \\
(82.5)\end{array}$ & $\begin{array}{c}37 \\
(17.5)\end{array}$ & $\begin{array}{c}85 \\
(98.8)\end{array}$ & $1(1.2)$ & $\begin{array}{l}151 \\
(90.4)\end{array}$ & $16(9.6)$ & $47(94.0)$ & $3(6)$ \\
\hline Q.3 & \multicolumn{3}{|c|}{$\begin{array}{l}\text { Forensic odontology is a promising } \\
\text { field in dentistry? }\end{array}$} & $\begin{array}{c}181 \\
(85.4)\end{array}$ & $\begin{array}{c}31 \\
(14.6)\end{array}$ & $\begin{array}{c}83 \\
(96.5)\end{array}$ & $3(3.5)$ & $\begin{array}{c}144 \\
(86.2)\end{array}$ & $\begin{array}{c}23 \\
(13.8)\end{array}$ & $45(90)$ & $5(10)$ \\
\hline Q.4 & \multicolumn{3}{|c|}{$\begin{array}{l}\text { Dental evidences play an important } \\
\text { role in forensic cases? }\end{array}$} & $\begin{array}{c}196 \\
(92.5)\end{array}$ & $\begin{array}{c}16 \\
(7.5)\end{array}$ & $\begin{array}{c}85 \\
(98.8)\end{array}$ & $1(1.2)$ & $\begin{array}{l}159 \\
(95.2)\end{array}$ & $8(4.8)$ & $49(98.0)$ & $1(20)$ \\
\hline Q.5 & \multicolumn{3}{|c|}{$\begin{array}{l}\text { Know any forensic cases solved using } \\
\text { dental evidences? }\end{array}$} & $\begin{array}{c}61 \\
(28.8)\end{array}$ & $\begin{array}{c}151 \\
(71.2)\end{array}$ & $\begin{array}{c}29 \\
(33.7)\end{array}$ & $57(66.3)$ & $56(33.5)$ & $\begin{array}{c}111 \\
(65.5)\end{array}$ & $17(34.0)$ & $\begin{array}{c}33 \\
(66)\end{array}$ \\
\hline Q.6 & \multicolumn{3}{|c|}{$\begin{array}{l}\text { Forensic odontology should be taught } \\
\text { as a separate subject at BDS level? }\end{array}$} & $\begin{array}{c}125 \\
(59.0)\end{array}$ & $87(41)$ & $\begin{array}{c}66 \\
(76.7)\end{array}$ & $20(23.3)$ & $97(58.1)$ & $\begin{array}{c}70 \\
(41.9)\end{array}$ & $41(82.0)$ & $9(18)$ \\
\hline Q.7 & \multicolumn{3}{|c|}{$\begin{array}{l}\text { Forensic odontology as a separate PG } \\
\text { course in India? }\end{array}$} & $\begin{array}{c}162 \\
(76.4)\end{array}$ & $\begin{array}{c}50 \\
(23.6) \\
\end{array}$ & $\begin{array}{c}70 \\
(81.4)\end{array}$ & $16(18.6)$ & $\begin{array}{c}139 \\
(83.2)\end{array}$ & $\begin{array}{c}28 \\
(16.8)\end{array}$ & $39(78.0)$ & $\begin{array}{c}11 \\
(22)\end{array}$ \\
\hline \multirow{3}{*}{$\begin{array}{l}\text { Question } \\
\text { number }\end{array}$} & \multicolumn{7}{|c|}{ Participants' response to Q. nos. 2-7 } & \multirow[t]{3}{*}{$\chi^{2}$} & & \multirow{3}{*}{\multicolumn{2}{|c|}{ Significant $^{* *}$}} \\
\hline & \multicolumn{2}{|c|}{ DAs $(n=53)$} & \multicolumn{2}{|c|}{$\begin{array}{l}\text { Both in DAs and } \\
\text { DPs }(n=39)\end{array}$} & \multicolumn{3}{|c|}{ Total $(n=607)$} & & & & \\
\hline & Yes $(\%)$ & No (\%) & Yes $(\%)$ & No (\%) & Yes $(\%)$ & & $(\%)$ & & & & \\
\hline Q.2 & $52(98.1)$ & $1(1.9)$ & $39(100)$ & $0(0)$ & $\begin{array}{c}549 \\
(90.4)\end{array}$ & & (9.6) & 30.77 & & 0.0 & \\
\hline Q.3 & $52(98.1)$ & $1(1.9)$ & 37 (94.9) & $2(5.1)$ & $\begin{array}{c}542 \\
(89.3)\end{array}$ & & 10.7) & 15.33 & & 0.0 & \\
\hline Q.4 & $53(100)$ & $0(0)$ & 39 (100) & $0(0)$ & $\begin{array}{c}581 \\
(95.7)\end{array}$ & & (4.3) & 12.41 & & 0.0 & \\
\hline Q.5 & $31(58.5)$ & $22(41.5)$ & $26(66.7)$ & $\begin{array}{c}13 \\
(33.3)\end{array}$ & $\begin{array}{c}220 \\
(36.2)\end{array}$ & 387 & 63.81) & 32.97 & & 0.0 & \\
\hline Q.6 & $42(79.2)$ & $11(20.8)$ & $27(69.2)$ & $\begin{array}{c}12 \\
(30.8)\end{array}$ & $\begin{array}{c}398 \\
(65.6)\end{array}$ & & $(34.4)$ & 23.60 & & 0.0 & \\
\hline Q.7 & $44(83)$ & $9(17)$ & $30(76.9)$ & $9(23.1)$ & $\begin{array}{c}484 \\
(79.7)\end{array}$ & & (20.3) & 3.50 & & 0.6 & \\
\hline
\end{tabular}

\footnotetext{
**Statistically significant at P<0.05. UG: Undergraduate, PG: Postgraduate; DP: Dental practitioner; DA: Dental academician
} 


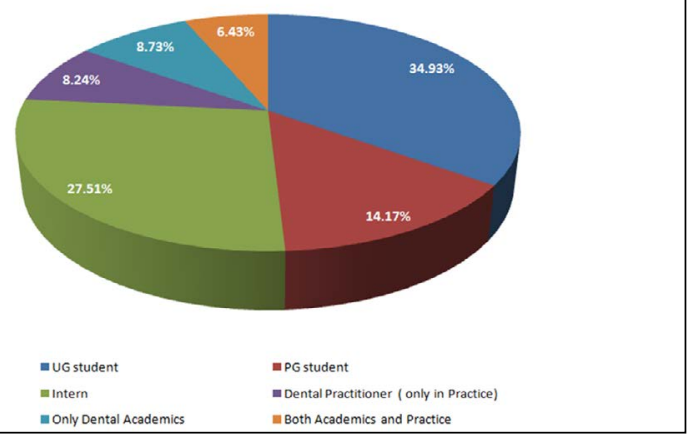

Figure 1: Pie chart showing the distribution of participating respondents in the survey $(n=607)$. FO: Forensic odontology, PG: Postgraduate, DPs: Dental practitioners, DAs: Dental academicians.

aware of the journal "JFDS" (Q. no. 11). Overall, 66\% of the respondents agreed for a separate subject on FO at the BDS level. There was a significant association in the response to this question (Q. no. 6) among the category of respondents. Eighty-two percentage of the DPs (Group 4) agreed for a separate subject on FO at the BDS level. Only $42 \%$ of the participants were aware of the PG courses in $\mathrm{FO}$ offered in foreign universities. Those participants who are both in academics and practice were more aware than the rest of the participants. Nearly $56 \%$ of the respondents were not aware of IAFO (Q. no. 10) and those in both academics and practice were more aware of the association (56.4\%). The respondents in Group 5 and Group 6 possessed greater knowledge and awareness of the academic and practical aspects of FO. Those who are in both academics and practice possessed more knowledge and awareness of FO than those who are exclusively in academics or practice. The Chi-square analysis revealed an insignificant difference $(P>0.05)$ in the responses between groups for Q. nos. 7, 12, and 13 [Tables 1 and $2]$. The answer to the other questions showed significant differences in the distribution of responses among the groups.

\section{Forensic Odontology as a Separate Postgraduate Course in India}

Nearly $80 \%$ of the respondents to Q. no. 7 agreed for a separate PG course in FO in India, out of which 36.6\% agreed for the MDS course and 33.3\% agreed for PG diploma course in FO. Fifty-seven out of 484 (11.8\%) and

Table 2. The distribution of the participants' responses to the Q. nos. 9-13 in the questionnaire

\begin{tabular}{|c|c|c|c|c|c|c|c|}
\hline \multirow{3}{*}{$\begin{array}{l}\text { Question } \\
\text { number }\end{array}$} & \multirow[t]{3}{*}{ Subject of the question } & \multicolumn{6}{|c|}{ Participants' response to Q. nos. 9-13 } \\
\hline & & \multicolumn{2}{|c|}{${ }^{\star}$ UG students $(n=212)$} & \multicolumn{2}{|c|}{ PG students $(n=86)$} & \multicolumn{2}{|c|}{ Interns $(n=167)$} \\
\hline & & Yes $(\%)$ & No $(\%)$ & Yes $(\%)$ & No $(\%)$ & Yes $(\%)$ & No $(\%)$ \\
\hline Q.9 & $\begin{array}{l}\text { Awareness on foreign universities offering } \\
\text { forensic odontology course? }\end{array}$ & $61(28.8)$ & $151(71.2)$ & $41(47.7)$ & $45(52.3)$ & $83(49.7)$ & $84(50.3)$ \\
\hline Q.10 & Awareness about IAFO? & $74(34.9)$ & $138(65.1)$ & $46(53.5)$ & $40(46.5)$ & $81(48.5)$ & $86(51.5)$ \\
\hline Q.11 & Awareness about JFDS? & $31(14.6)$ & $181(85.4)$ & $56(65.1)$ & $30(34.9)$ & $53(31.7)$ & $114(68.3)$ \\
\hline Q.12 & $\begin{array}{l}\text { Awareness about the role of forensic } \\
\text { odontology in Nirbhaya case? }\end{array}$ & $92(43.4)$ & $120(56.6)$ & $36(41.9)$ & $50(58.1)$ & $83(49.7)$ & $84(50.3)$ \\
\hline Q.13 & $\begin{array}{l}\text { BDS degree is the minimum qualification } \\
\text { needed to give expert opinion? }\end{array}$ & $145(68.4)$ & $67(31.6)$ & $46(53.5)$ & $40(46.5)$ & $106(63.5)$ & $61(36.5)$ \\
\hline
\end{tabular}

\begin{tabular}{|c|c|c|c|c|c|c|c|c|c|c|c|}
\hline \multirow{3}{*}{$\begin{array}{l}\text { Question } \\
\text { number }\end{array}$} & \multicolumn{8}{|c|}{ Participants' response to Q. nos. 9-13 } & \multirow[t]{3}{*}{$\chi^{2}$} & \multirow[t]{3}{*}{ df } & \multirow[t]{3}{*}{ Significant $^{* *}$} \\
\hline & \multicolumn{2}{|c|}{ DPs $(n=50)$} & \multicolumn{2}{|c|}{ DAs $(n=53)$} & \multicolumn{2}{|c|}{ DPs + DAs $(n=39)$} & \multicolumn{2}{|c|}{ Total $(n=607)$} & & & \\
\hline & Yes (\%) & No (\%) & Yes $(\%)$ & No $(\%)$ & Yes (\%) & No (\%) & Yes (\%) & No (\%) & & & \\
\hline Q.9 & $20(40)$ & $30(60)$ & $25(47.2)$ & $28(52.8)$ & $25(64.1)$ & $14(35.9)$ & $255(42)$ & $352(58)$ & 28.91 & 5 & 0.000 \\
\hline Q.10 & $24(48)$ & $26(52)$ & $21(39.6)$ & $32(60.4)$ & $22(56.4)$ & $17(43.6)$ & $268(44.2)$ & $339(55.8)$ & 14.8 & & 0.011 \\
\hline Q.11 & $16(32)$ & $34(68)$ & $28(52.8)$ & $25(47.2)$ & $31(79.5)$ & $8(20.5)$ & $215(35.4)$ & $392(64.6)$ & 114.62 & & 0.000 \\
\hline Q.12 & $24(48)$ & $26(52)$ & $31(58.5)$ & $22(41.5)$ & $23(59)$ & $16(41)$ & $289(47.6)$ & $318(52.4)$ & 7.48 & & 0.187 \\
\hline Q.13 & $38(76)$ & $12(24)$ & $37(69.8)$ & $16(30.2)$ & $28(71.8)$ & $11(28.2)$ & $400(65.9)$ & $207(34.1)$ & 10.15 & & 0.071 \\
\hline
\end{tabular}

**Statistically significant at $P<0.05$. UG: Undergraduate, PG: Postgraduate; DP: Dental practitioner; DA: Dental academician, JFDS: Journal of Forensic Dental Sciences 
agreed on the MSc course in the FO course [Table 3 and Figure 4].

\section{The Most Promising Topic in Forensic Odontology (Q. no. 14)}

Out of the four options mentioned in the questionnaire, nearly $88 \%$ of the participants opted for bitemark analysis and dental age estimation as the most promising topics in FO. Dental age estimation was opted more by the DAs and DPs, whereas bitemark was more answered by the other groups. The palatal rugae topic (4\%) was the least preferred in this survey. There was a significant difference in the distribution of differences between the study groups [Table 4 and Figure 5].

\section{Discussion}

The practical application and the academic training of FO subject are steadily gaining importance in India. The present survey was conducted in order to evaluate the strength of awareness of this budding specialty. In the present questionnaire-based study, there was participation of representatives from dental education, dental academics, and dental practice across the state of Gujarat. Thus, this study reflects the current situation of FO among different categories of present and future dental professionals. The present study though collected the responses from different cities of Gujarat state did not attempt to assess the city-wise difference in the responses of the participants. However, the association of the response rate among different groups of participants was assessed statistically. A study by Khare et al. with DPs and
DAs as participants was conducted in two different cities of India. ${ }^{4}$ They revealed that the participants from the metro city had more knowledge about FO than the participants from the one-tier city. In the present study, a majority (>90\%) of the UG and PG students and the dental interns were aware of FO as a subject, but only $31.4 \%$ were aware of any forensic cases solved using dental evidence. A study similar to the present one, in terms of the participants' groups, done by Wadhwan et al. ${ }^{5}$ at Ghaziabad revealed that the UG and the PG students were not having adequate knowledge on FO though many of the respondents were aware of the role of the dentist in mass disasters. None of the participants in their study were aware of the significance of bitemarks. However, in the present study, nearly $82 \%$ of the UGs and $99 \%$ of the PGs were aware of FO and bitemark analysis was considered one of the promising domains of FO by $47 \%$ of the respondents. Another study ${ }^{6}$ done among 100 UG and PG students of Chennai revealed that only $2 / 3^{\text {rd }}$ of the dental students have adequate knowledge about FO. They concluded that there is no adequate theoretical and practical exposure in forensic dentistry at the UG and PG curriculum. To address this issue, a need for a dedicated FO department or unit in dental institutes was highlighted in the author's earlier publication. ${ }^{3}$ We found that dental professionals in academics are more aware of FO, and 95\% of them accepted FO as a promising field in dentistry. A recent study ${ }^{2}$ from Delhi among the dental teaching staff concluded that there was sufficient knowledge of FO among dental teachers, but they lacked awareness and interest on the subject. In the present study, $98.1 \%$ of the DA knew FO and all of them agreed to the fact that dental evidence plays an important role in forensic cases.

Table 3. Participant-wise distribution of response to question number 8

\begin{tabular}{|c|c|c|c|c|c|c|c|c|c|}
\hline \multirow[t]{2}{*}{ Group } & \multirow[t]{2}{*}{ Participants } & \multicolumn{5}{|c|}{ Count (\%) } & \multirow[t]{2}{*}{$\chi^{2}$} & \multirow[t]{2}{*}{ df } & \multirow[t]{2}{*}{ Significant $^{*}$} \\
\hline & & $\begin{array}{l}\text { MSc. in } \\
\text { FO }\end{array}$ & $\begin{array}{c}\text { MDS in } \\
\text { FO }\end{array}$ & $\begin{array}{c}\text { PG } \\
\text { diploma in } \\
\text { FO }\end{array}$ & $\begin{array}{l}\text { Certificate } \\
\text { course } \\
\text { in FO } \\
\end{array}$ & Total & & & \\
\hline 1 & UG student & $23(14.2)$ & $80(49.4)$ & $25(15.4)$ & $34(21)$ & $162(33.5)$ & 67.717 & 5 & 0.000 \\
\hline 2 & PG student & $9(12.9)$ & $20(28.6)$ & $31(44.3)$ & $10(14)$ & $70(14.5)$ & & & \\
\hline 3 & Intern & $6(4.3)$ & $45(32.4)$ & $57(41.0)$ & $31(22)$ & $139(28.7)$ & & & \\
\hline 4 & $\begin{array}{l}\mathrm{DP} \text { (only in } \\
\text { practice) }\end{array}$ & $10(25.6)$ & $9(23.1)$ & $12(30.8)$ & $8(21)$ & $39(8.1)$ & & & \\
\hline 5 & Only DAs & $4(9.1)$ & $9(20.5)$ & $27(61.4)$ & $4(9)$ & $44(9.1)$ & & & \\
\hline 6 & Both DAs and DPs & $5(16.7)$ & $14(46.7)$ & $9(30.0)$ & $2(7)$ & $30(6.2)$ & & & \\
\hline Total & & $57(11.8)$ & $177(36.6)$ & $161(33.3)$ & $89(18)$ & $484(100.0)$ & & & \\
\hline
\end{tabular}

*Statistically significant at $P<0.05$. UG: Undergraduate, PG: Postgraduate, DPs: Dental practitioners, DAs: Dental academicians, FO: Forensic odontology 


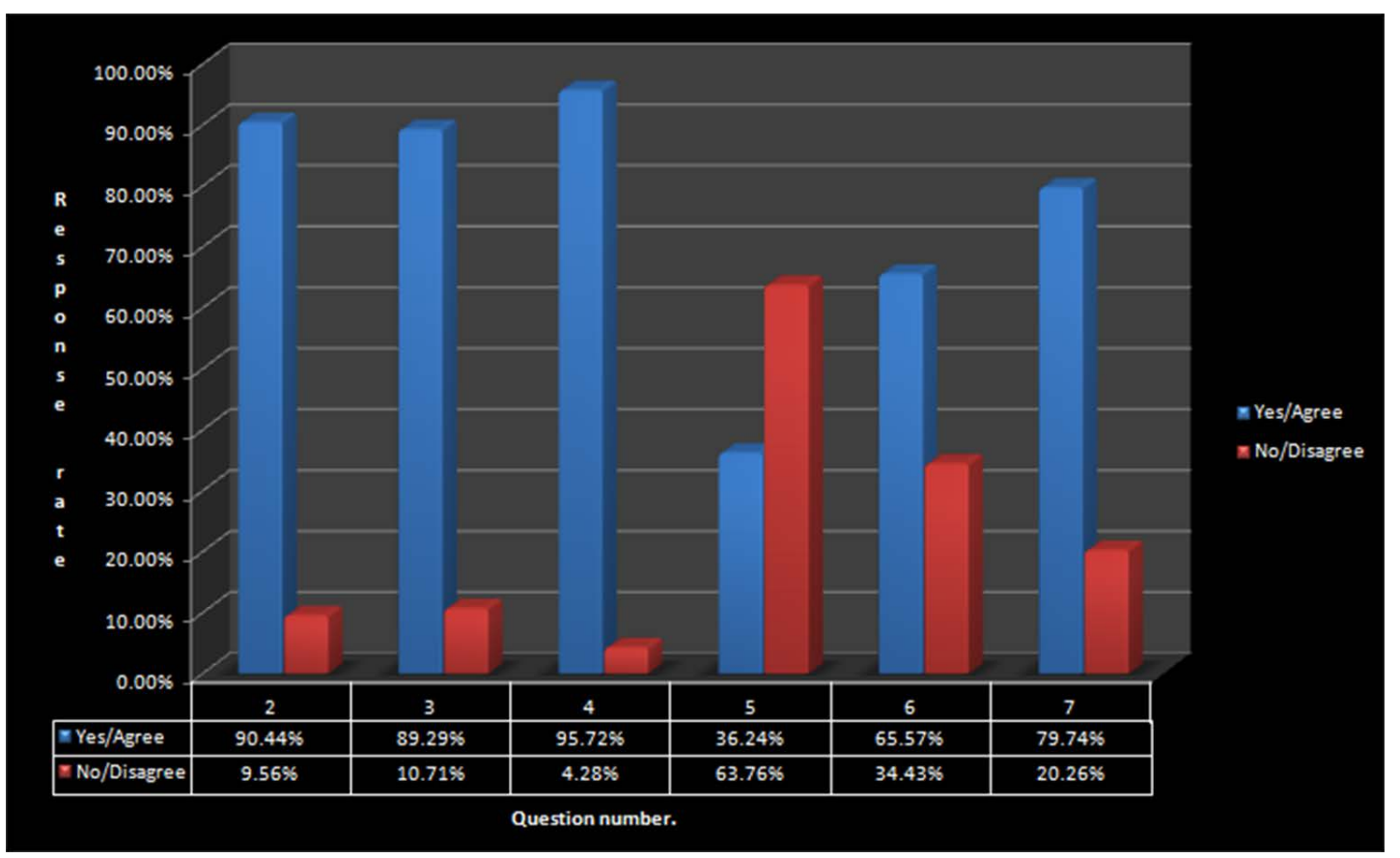

Figure 2: Chart showing the distribution of the overall responses to questions 2-7.

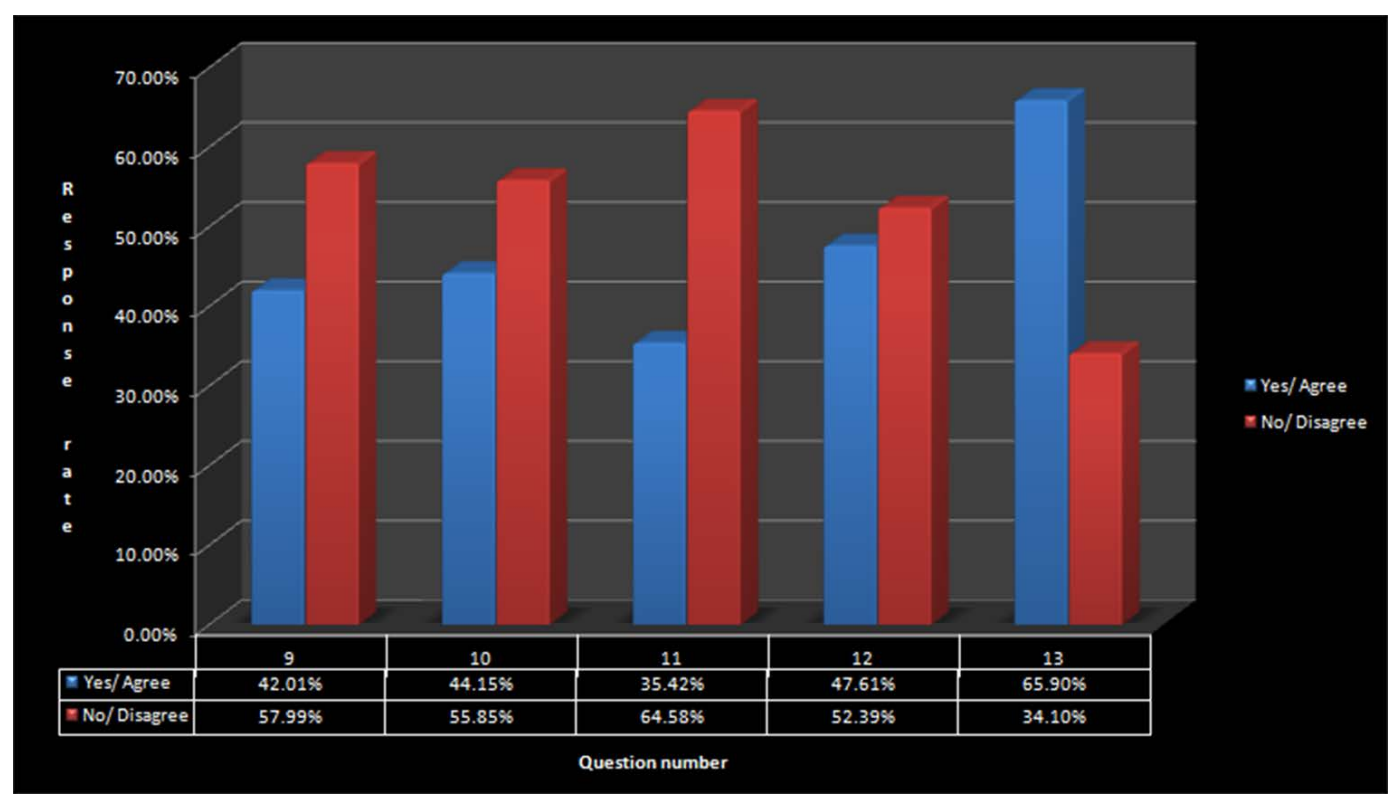

Figure 3: Chart showing the distribution of the overall responses to questions 9-13.

Sixty-six percentage of the respondents in the present study opted for FO as a separate subject at UG level and $80 \%$ of them wanted FO as a separate branch at the PG level. We did not come across any survey addressing the need for FO as a separate branch at UG and PG level. The revised DCI regulation for BDS in 2007 included $40 \mathrm{~h}$ of didactic lectures and practical in FO in 3rd-year oral pathology subjects. ${ }^{6}$ A cross-sectional study ${ }^{7}$ done among 235 DPs in Kashmir valley revealed that the DPs lacked confidence in handling forensic-related cases, and the majority of the respondents lacked formal training in FO. A similar study done in Ghaziabad among DPs revealed inadequate knowledge about $\mathrm{FO}$ in $>90 \%$ of the respondents. ${ }^{8}$ This is contrary to the results of the present 
Table 4. Participant-wise distribution of responses to question number 14

\begin{tabular}{|c|c|c|c|c|c|c|c|c|c|}
\hline \multirow[t]{2}{*}{ Group } & \multirow[t]{2}{*}{ Participants } & \multicolumn{5}{|c|}{ Count (\%) } & \multirow[t]{2}{*}{$x^{2}$} & \multirow[t]{2}{*}{ df } & \multirow[t]{2}{*}{ Significant $^{\star}$} \\
\hline & & $\begin{array}{l}\text { Dental age } \\
\text { estimation }\end{array}$ & $\begin{array}{l}\text { Bitemark } \\
\text { analysis }\end{array}$ & $\begin{array}{l}\text { Lip print } \\
\text { analysis }\end{array}$ & $\begin{array}{c}\text { Palatal } \\
\text { rugae } \\
\text { analysis }\end{array}$ & Total & & & \\
\hline 1 & UG student & $69(32.5)$ & $113(53.3)$ & $21(9.9)$ & $9(4)$ & $212(34.9)$ & 34.27 & 5 & 0.003 \\
\hline 2 & PG student & $36(41.9)$ & $34(39.5)$ & $11(12.8)$ & $5(6)$ & $86(14.2)$ & & & \\
\hline 3 & Intern & $73(43.7)$ & $80(47.9)$ & $11(6.6)$ & $3(2)$ & $167(27.5)$ & & & \\
\hline 4 & DP (only in practice) & $14(28.0)$ & $29(58.0)$ & $5(10.0)$ & $2(4)$ & $50(8.2)$ & & & \\
\hline 5 & Only DAs & $31(58.5)$ & $15(28.3)$ & $2(3.8)$ & $5(9)$ & $53(8.7)$ & & & \\
\hline 6 & Both DAs and DPs & $21(53.8)$ & $17(43.6)$ & $1(2.6)$ & $0(0)$ & $39(6.4)$ & & & \\
\hline Total & & $244(40.2)$ & $288(47.4)$ & $51(8.4)$ & $24(4)$ & $607(100.0)$ & & & \\
\hline
\end{tabular}

*Statistically significant at $P<0.05$. UG: Undergraduate, PG: Postgraduate, DPs: Dental practitioners; DAs: Dental academicians

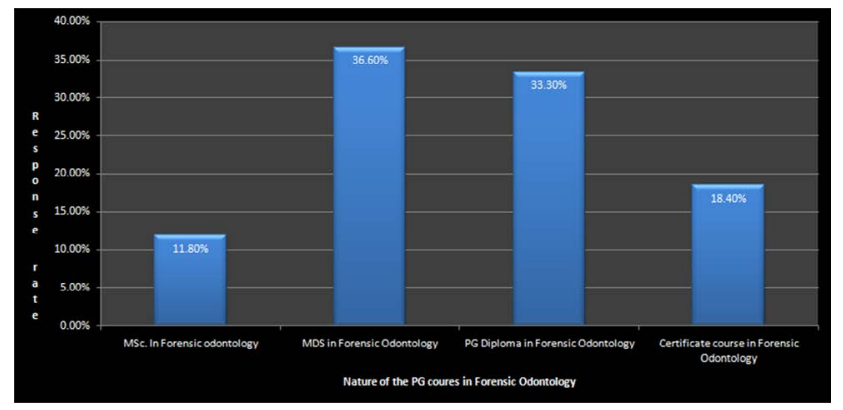

Figure 4: Chart showing the percentage of the overall responses to Q.no.8 by the participants. Pearson's Chi Square $\chi^{2}(d f=5, n=607, P<0.001)=67.72$, FO: Forensic odontology, PG: Postgraduate.

study. Their study classified DPs into BDS and MDS practitioners. However, the present one considered both under one category. In the present study also, $66 \%$ of the DPs were not aware of any forensic cases solved using dental evidence. A recent systematic review of questionnaire studies done in several parts of India at different points of time revealed a limited knowledge and awareness level of the respondents on the awareness and knowledge of FO. The study also showed that the respondents had inadequate knowledge about the practical application of FO in routine dental practice. The study recommended the introduction of a separate course on FO by the DCI. ${ }^{9}$ Most of the earlier studies have included maintaining dental records as one of the issues in their studies. A study by Nagarajappa et al. ${ }^{10}$ in Kanpur showed that all the DPs in their survey had maintained dental records and possessed adequate knowledge and a good attitude toward FO. The present study did not include questions related to dental records. Another recent study in Kanpur revealed inadequate knowledge of FO in $70 \%$ of the DPs. ${ }^{11}$ The DPs in Varanasi city also revealed inadequate knowledge and awareness of FO. ${ }^{12}$ Harchandani et al. conducted a cross-sectional study of 300 DPs in Pune. ${ }^{13}$ They observed that $70 \%$ of the practitioners maintained dental records and $61 \%$ did not know about child abuse. In the present study, the DPs constituted only $8.24 \%$ of the sample, and questions related to dental record and child abuse were not included in the questionnaire. Their study further revealed poor attitude and clinical knowledge in FO, and $83 \%$ of the participants lacked proper training in collecting, evaluating, and presenting dental evidence. The general DPs also need to understand the forensic implication of the practice in the form of maintaining the dental records and providing the same for comparisons when the need arises. Only $14 \%$ of the BDS and $29 \%$ of the MDS practitioners in Varanasi were aware of the importance of dental records. ${ }^{12}$ A study similar to the present one was conducted in Punjab to assess the awareness of FO among UG students, PG students, and DPs. ${ }^{14}$ The study revealed that $97.3 \%$ of the PG students agreed for a separate subject of FO at UG level. The present study showed that $77 \%$ of the PG students agreed for a separate subject of FO in the UG curriculum, whereas $81 \%$ of the PG students agreed for a separate PG course in FO. A study among DPs in Chennai revealed that only $27 \%$ were aware of an association for FO in India (IAFO).${ }^{15}$ In the present study, an overall $44.2 \%$ were aware of IAFO, and there was a significant difference in the response rate among the different categories of respondents. More than 50\% of those who are only in dental practice and more than $60 \%$ of those only in dental academics were not aware of IAFO, 


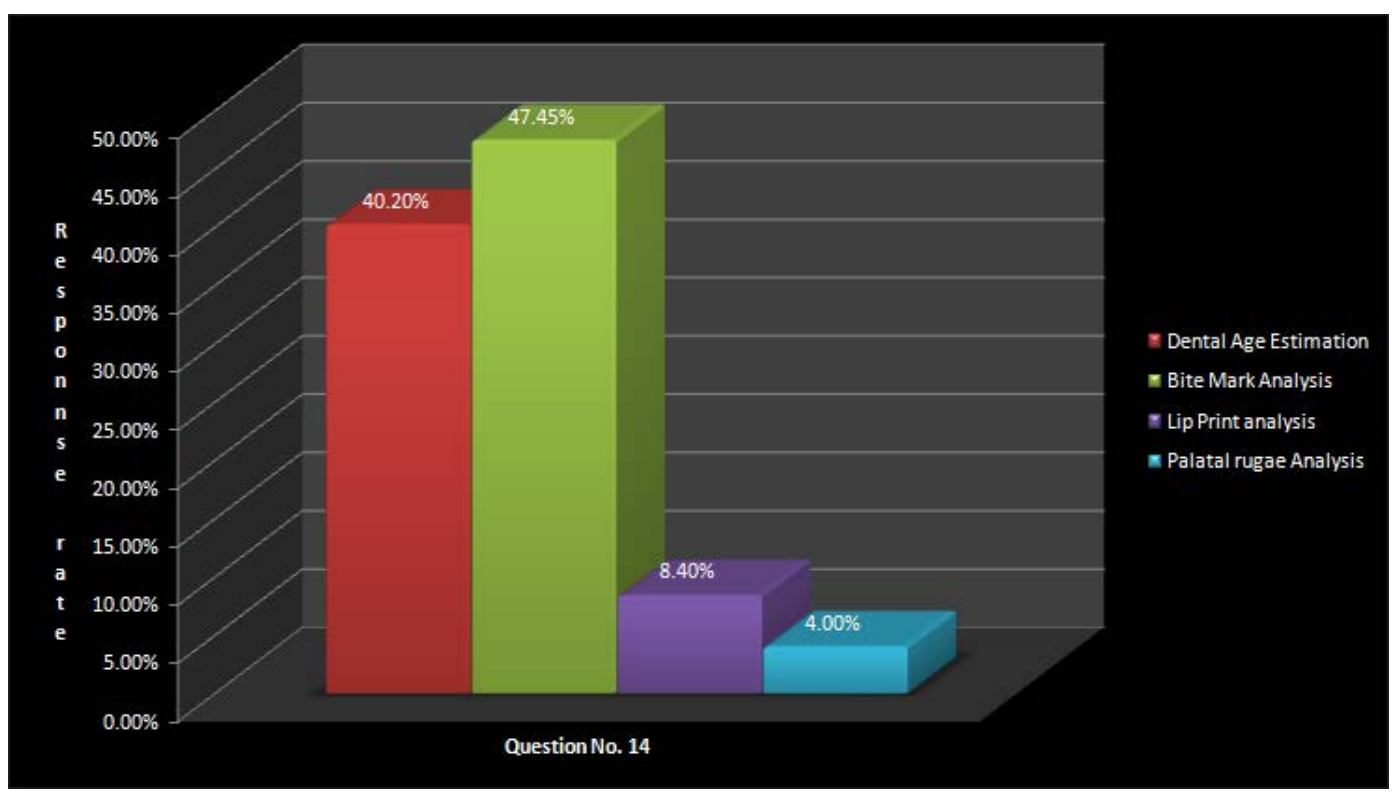

Figure 5: Chart showing the percentage of the overall responses to question number 14 by the participants. Pearson's Chi Square $\chi^{2}(\mathrm{df}=5, \mathrm{n}=607, \mathrm{P}<0.05)=34.27$.

Table 5. Perception and level of knowledge of FO among stakeholders from different parts of India

\begin{tabular}{|c|c|c|c|c|c|}
\hline $\begin{array}{l}\text { Sr. } \\
\text { No. }\end{array}$ & Authors & Year & Place & Participants (N) & Key findings \\
\hline 1 & Preeti et $a l^{6}$ & 2011 & Chennai & $\begin{array}{c}\text { Dental } \\
\text { practitioners } \\
(322)\end{array}$ & $\begin{array}{l}\text { - } 41 \% \text { did not know about dental age } \\
\text { estimation. } \\
\text { - } 18 \% \text { did not know the significance of bite } \\
\text { mark. } \\
\text { - } 30 \% \text { did not know they can testify as an } \\
\text { expert witness in the court of law. }\end{array}$ \\
\hline 2 & Shetty and Raviprakash ${ }^{24}$ & 2011 & India & $\begin{array}{l}\text { Oral Pathologist } \\
\qquad(120)\end{array}$ & $\begin{array}{l}\text { - } 28 \% \text { expressed confidence in handling } \\
\text { forensic cases and } 7 \% \text { had formal FO } \\
\text { training. } \\
\text { - } 6 \% \text { had handled forensic cases. }\end{array}$ \\
\hline 3 & Khare $e t a l^{4}$ & 2013 & $\begin{array}{l}\text { India (one } \\
\text { metro and one } \\
\text { tier } 2 \text { city) }\end{array}$ & $\begin{array}{l}\text { Dental } \\
\text { practitioners and } \\
\text { academicians } \\
(774))\end{array}$ & $\begin{array}{l}\text { - Respondents from Metro city had more } \\
\text { knowledge about FO. } \\
\text { - Respondents from tier } 2 \text { city had more } \\
\text { interest in becoming member of IAFO } \\
\text { than metro city respondents. } \\
\text { - No significant difference in the mean } \\
\text { scores of Knowledge, attitude and } \\
\text { practice of FO among respondents from } \\
\text { two cities. }\end{array}$ \\
\hline 4 & Nagarajappa et al ${ }^{10}$ & 2014 & Kanpur & $\begin{array}{l}\text { Dental } \\
\text { Practitioners } \\
\quad(149)\end{array}$ & $\begin{array}{l}\text { - Lack of practice in maintaining dental } \\
\text { records. } \\
\text { - adequate knowledge and good attitude. }\end{array}$ \\
\hline
\end{tabular}




\begin{tabular}{|c|c|c|c|c|c|}
\hline 5 & Ranganthan et al ${ }^{27}$ & 2014 & Chennai & $\begin{array}{l}\text { Legal } \\
\text { Professionals } \\
\text { (200) }\end{array}$ & $\begin{array}{l}\text { - Lawyers aged above } 40 \text { years and lawyers } \\
\text { having more than } 20 \text { years of experience } \\
\text { were having more knowledge on forensic } \\
\text { odontology. } \\
\text { - Males were more aware of forensic } \\
\text { odontology with respect to criminal } \\
\text { identification. } \\
\text { - The lawyers practicing in both civil and } \\
\text { criminal cases were more aware of bite } \\
\text { mark analysis. }\end{array}$ \\
\hline 6 & Wadhwan et al ${ }^{5}$ & 2014 & India & $\begin{array}{l}\text { UGs, Interns, } \\
\text { PGs, Dental } \\
\text { Practitioners } \\
\text { (200) }\end{array}$ & $\begin{array}{l}\text { - Every respondent was aware of FO as a } \\
\text { speciality. } \\
\text { - PGs and Clinicians were not confident } \\
\text { about handling forensic odontology } \\
\text { cases. } \\
\text { - UGs, Interns and PGs were felt that their } \\
\text { knowledge on FO is inadequate. } \\
\text { - None of the respondents were aware of } \\
\text { the significance of Bitemarks. }\end{array}$ \\
\hline 7 & N.N.Singh et al ${ }^{7}$ & 2014 & Kashmir Valley & $\begin{array}{c}\text { Dental } \\
\text { Practitioners }\end{array}$ & $\begin{array}{l}\text { - 94\% did not have any practical training in } \\
\text { FO; } 81 \% \text { were not having confidence in } \\
\text { handling forensic cases. }\end{array}$ \\
\hline 8 & Sharma A et al ${ }^{8}$ & 2015 & Ghaziabad & $\begin{array}{l}\text { Dental } \\
\text { Practitioners } \\
\text { (137) }\end{array}$ & $\begin{array}{l}\text { - More than } 95 \% \text { of the subjects were not } \\
\text { having confidence in handling forensic } \\
\text { cases. } \\
\text { - MDS dental practitioners were having } \\
\text { better knowledge and awareness } \\
\text { about Forensic Odontology than BDS } \\
\text { practitioners. }\end{array}$ \\
\hline 9 & Navya and Raj ${ }^{15}$ & 2016 & Chennai & $\begin{array}{l}\text { Dental } \\
\text { Practitioners } \\
\text { (200) }\end{array}$ & $\begin{array}{l}\text { - Only } 2 \% \text { of the subjects knew about the } \\
\text { forensic courses in India. } 27 \% \text { of the } \\
\text { subjects knew about IAFO. } \\
\text { - } 69 \% \text { of the subjects were not confident } \\
\text { about giving expert opinion in forensic } \\
\text { cases. }\end{array}$ \\
\hline 10 & Pandit et al ${ }^{28}$ & 2016 & Mysore & Police Officers & $\begin{array}{l}\text { - Newspapers were the main source of } \\
\text { knowledge. }\end{array}$ \\
\hline 11 & Dany SS et al ${ }^{17}$ & 2016 & Odisha & $\begin{array}{c}\text { Dental Surgeons } \\
(240)\end{array}$ & $\begin{array}{l}\text { - } 96.25 \% \text { of the participants did not have } \\
\text { any formal training in FO. }\end{array}$ \\
\hline
\end{tabular}




\begin{tabular}{|c|c|c|c|c|c|}
\hline 12 & Sahni et al $^{2}$ & 2016 & Delhi NCR & $\begin{array}{l}\text { Dental Faculties } \\
\qquad(200)\end{array}$ & $\begin{array}{l}\text { - Possessed sufficient knowledge but less } \\
\text { awareness and interest in FO. } \\
\text { - } 59 \% \text { of the teaching faculties were not } \\
\text { aware of the fact that FO should be taught } \\
\text { to UG students as per the DCI norms. } \\
\text { - } 94 \% \text { of the respondents agreed to undergo } \\
\text { formal training in FO. }\end{array}$ \\
\hline 13 & Hannah et al ${ }^{18}$ & 2017 & Chennai & $\begin{array}{l}\text { UG Dental } \\
\text { students } \\
(154)\end{array}$ & $\begin{array}{l}\text { - }>80 \% \text { of the students have good } \\
\text { knowledge about FO. The major source of } \\
\text { knowledge was through workshops and } \\
\text { lectures. Nearly } 90 \% \text { agreed that there is } \\
\text { a good scope for FO. }\end{array}$ \\
\hline 14 & Bhakhri et al ${ }^{19}$ & 2017 & Patiala & $\begin{array}{c}\text { Interns and } \\
\text { Dental Faculties } \\
(152)\end{array}$ & $\begin{array}{l}\text { - } 88 \% \text { were aware of role of liprtints in FO } \\
\text { and } 85.3 \% \text { agreed to attend CDEs on FO. }\end{array}$ \\
\hline 15 & Rahman et al ${ }^{20}$ & 2017 & Bhubaneswar & $\begin{array}{c}\text { Dental surgeons } \\
(276)\end{array}$ & $\begin{array}{l}\text { - There is an adequate level of knowledge } \\
\text { and awareness about FO among } \\
\text { practicing dental surgeons and interns. }\end{array}$ \\
\hline 16 & Saima Sultan ${ }^{29}$ & 2017 & Srinagar & $\begin{array}{l}\text { Lawyers } \\
(250)\end{array}$ & $\begin{array}{l}\text { - No Knowledge and awareness about } \\
\text { forensic odontology and child abuse. }\end{array}$ \\
\hline 17 & Rubel et al ${ }^{21}$ & 2017 & Davangre & $\begin{array}{l}\text { Dental } \\
\text { Practitioners } \\
\quad(200)\end{array}$ & $\begin{array}{l}\text { - } 49.5 \% \text { of the participants had a part of FO } \\
\text { in their curriculum. } 86.5 \% \text { did not have } \\
\text { formal training in dealing with dental } \\
\text { evidences. } 75 \% \text { of the practicing dentists } \\
\text { never practiced FO. }\end{array}$ \\
\hline 18 & Rudraswamy et al 22 & 2017 & Mysore & $\begin{array}{l}\text { Dental students } \\
(183)\end{array}$ & $\begin{array}{l}\text { - Around } 87 \% \text { were aware that dentist can } \\
\text { testify as expert witness in the court of } \\
\text { law. } \\
\text { - Need to introduce FO in BDS curriculum } \\
\text { as a separate subject. }\end{array}$ \\
\hline 19 & Narayanan et al ${ }^{23}$ & 2017 & Mangalore & $\begin{array}{l}\text { Dental students, } \\
\text { faculties and } \\
\text { practitioners }\end{array}$ & $\begin{array}{l}\text { - } 85 \% \text { believe that FO should be taught in } \\
\text { UG curriculum. } \\
\text { - } 70 \% \text { feel that FO should be under oral } \\
\text { pathology department. }\end{array}$ \\
\hline 15 & Kumaraswamy et al ${ }^{25}$ & 2018 & Bengaluru & $\begin{array}{l}\text { Medical students } \\
\text { (194) }\end{array}$ & $\begin{array}{l}\text { - } 65 \% \text { considered Forensic odontologists } \\
\text { as identification experts. } 52 \% \text { knew the } \\
\text { importance of dental evidences. } \\
\text { - } 99 \% \text { agreed that FO is a part of forensic } \\
\text { medicine. }\end{array}$ \\
\hline 16 & Shivakumar GC ${ }^{12}$ & 2018 & Varanasi city & $\begin{array}{l}\text { Dental } \\
\text { Practitioners } \\
\quad(172)\end{array}$ & $\begin{array}{l}\text { - Inadequate knowledge and awareness } \\
\text { towards FO. Only } 14 \% \text { of the BDS and } \\
29 \% \text { of the MDS practitioners were aware } \\
\text { of the importance of dental records. }\end{array}$ \\
\hline
\end{tabular}




\begin{tabular}{|c|c|c|c|c|c|}
\hline 17 & Sharma D et al ${ }^{30}$ & 2018 & Ludhiana & $\begin{array}{l}\text { Police officials } \\
\quad(350)\end{array}$ & $\begin{array}{l}\text { - The police officials irrespective of their } \\
\text { rank had sufficient knowledge about the } \\
\text { role of FO in age estimation. } \\
\text { - } 38 \% \text { of the participants were aware of the } \\
\text { role of FO in Nirbhaya case. } \\
\text { - About } 68 . \& \% \text { of high rank officers were } \\
\text { aware of the fact that dental evidence play } \\
\text { a substantial role in the context of law. }\end{array}$ \\
\hline 17 & Isher DK et al ${ }^{14}$ & 2019 & Punjab & $\begin{array}{l}\text { UG Students, PG } \\
\text { students, Dental } \\
\text { practitioners }\end{array}$ & $\begin{array}{l}\text { - Inadequate knowledge, poor attitude and } \\
\text { lack of practice. } \\
\text { - General awareness about FO was more } \\
\text { among the UG students than the PGs. } \\
\text { - } 97.3 \% \text { of the PGs agreed for a separate } \\
\text { subject of FO in the UG level. }\end{array}$ \\
\hline 18 & Roy et $a^{26}$ & 2019 & Central Kerala & $\begin{array}{c}\text { Medical } \\
\text { Practitioners } \\
(200)\end{array}$ & $\begin{array}{l}\text { Practitioners with more than } 15 \text { years of } \\
\text { practice had more knowledge. Awareness } \\
\text { of modern FO techniques and procedures } \\
\text { were more in practitioners with less than } \\
15 \text { years of experience. }\end{array}$ \\
\hline 19 & Mehrotra et $a l^{11}$ & 2019 & Kanpur & $\begin{array}{l}\text { Dental } \\
\text { Prctitioners } \\
(207)\end{array}$ & $\begin{array}{l}\text { - Around } 69.5 \% \text { of the general dental } \\
\text { practitioners were having knowledge } \\
\text { and perception about the role of dentist } \\
\text { in forensic Odontology } 70 \% \text { agreed } \\
\text { that their knowledge regarding FO is } \\
\text { inadequate and } 79 \% \text { were willing to } \\
\text { attend the CDEs on FO. }\end{array}$ \\
\hline
\end{tabular}

whereas those who are both in dental practice and dental academics are much aware of IAFO (56.4\%). The PG students were much aware of IAFO than the UG students. The IAFO is a professional organization, primarily of dentists in India, furthering the specialty of forensic dentistry, which was formed in the year 2000 with nearly 490 members. ${ }^{16}$ There are several articles related to the perception of FO and the level of knowledge of the subject among several stakeholders including dental students, DPs, and DAs from different parts of India ${ }^{17-23}$ [Table 5]. The present study is the first such report from the state of Gujarat with participants from cities such as Ahmedabad, Baroda, Surat, Gandhinagar, and Rajkot. The literature search also revealed questionnaire studies conducted among dental specialties and nondental professionals. ${ }^{24-30}$ Sixty-five percent of medical students in a study in Bengaluru considered forensic odontologists as identification experts and $99 \%$ agreed that FO is a part of forensic medicine. Police and the legal professionals are the main stakeholders required for the advancements of the practical application of FO in India. When compared to the number of FO awareness studies among dental professionals, there are very few studies done on a similar topic among the police and law personnel. In addition, some of the published studies show inadequate knowledge and awareness of FO among them. Currently, there are many qualified forensic odontologists available in India and hence their knowledge and skill may be applied to train these police and law personnel. For this science of FO to advance and mature into a separate specialty, multidisciplinary approaches involving all the stakeholders need to be incorporated.

\section{Conclusion}

- The awareness, knowledge, and interest among dental surgeons have increased in the subject of FO. However, 
all of them are not exposed to the practical application of this subject.

- The incidences of crime rate and natural and unnatural calamities are increasing nowadays, resulting in mass causalities. A properly trained forensic odontologist can contribute and play a significant role in the identification of persons during such untoward incidences.

- The forensic odontologist also has to sensitize the stakeholders from the police, the law, and the forensic medicine departments about the importance and application of FO.

- The government dental institutes that often deals with the forensic cases, involving age estimation, sex determination or any criminal cases under IPC 375 , CrPC 174, or medical negligence cases may incorporate the stakeholders and also the budding forensic odontologists on academic basis.

\section{Acknowledgment}

The authors wish to acknowledge Dr. Nupur Patel, Dr. Radha Patel, and Dr. Meghal Patel for their assistance and all the participants for their sincere contribution towards this questionnaire survey.

\section{Financial Support and Sponsorship}

Nil.

\section{Conflicts of Interest}

There are no conflicts of interest.

\section{References}

1. Acharya $\mathrm{AB}$, Sivapathasundharam B. Forensic Odontology. Shafer's Textbook of Oral Pathology. 5th ed. Elsevier, Gurgaon- India; 2006. p. 1199227.

2. Sahni A, Rehani S, Mathias Y, Kardam P, Nagpal R, Kumari R. A questionnaire survey on forensic odontology: Are we really aware? J Forensic Dent Sci 2016;8:113.

3. Pillai JP, Chokkalingam TS, Aasaithambi B, Nuzzolese E. Establishment of the forensic odontology department: A proposed model for the basic infrastructure and forensic odontology kit. J Forensic Dent Sci 2019;11:64-72.
4. Khare P, Chandra S, Raj V, Verma P, Subha G, Khare A. Status of forensic odontology in metro and in tier 2 city in urban India. J Forensic Dent Sci 2013;5:134-7.

5. Wadhwan V, Shetty DC, Jain A, Khanna KS, Gupta A. A call for a new speciality: Forensic odontology as a subject. J Forensic Dent Sci 2014;6:97-100.

6. Preethi S, Einstein A, Sivapathasundharam B. Awareness of forensic odontology among dental practitioners in Chennai: A knowledge, attitude, practice study. J Forensic Dent Sci 2011;3:63-6.

7. Singh NN, Gowhar O, Ain TS, Sultan S. Exploring trends in forensic odontology. J Clin Diagn Res 2014;8:ZC28-30.

8. Sharma A, Shokeen S, Arora R, Dhaginakatti SA. Survey on knowledge, attitude and practice forensic odontology among private dental practitioners in Ghaziabad city, India. J Dent Specialities 2015;3:43-7.

9. Gambhir RS, Singh G, Talwar PS, Gambhir J, Munjal V. Knowledge and awareness of forensic odontology among dentists in India: A systematic review. J Forensic Dent Sci 2016;8:2-6.

10. Nagarajappa R, Mehta M, Shukla N, Tuteja JS, Bhalla A. Awareness of forensic odontology among dental practitioners in Kanpur City, India: A KAP study. J Dent Res Updates 2014;1:6-12.

11. Mehrotra V, Mishra G, Sachdev R, Garg K, Mukherjee S, Saxena S. Perception of dental practitioners in and around Kanpur city towards forensic odontology: A cross sectional study. Int J Res Med Sci 2019;7:2732-6.

12. Shivakumar GC, Srivastava A, Shivakumar S. Knowledge and attitude assessment of dental practitioners towards forensic odontology in Varanasi City. Int J Scientific Res Rev 2018;6:533-38.

13. Harchandani N, Marathe S, Hebbale M, Ul Nisa S, Hiremutt D. Awareness of forensic odontology among general dental practitioners in Pune A cross-sectional study. J Adv Med Dent Sci Res 2014;2:10-6.

14. Isher DK, Singh Isher PP, Kaur N, Rakhra J. Knowledge, awareness and practice of forensic odontology among the dentists of Punjab. J Indian Acad Oral Med Radiol 2019;31:239-45.

15. Navya N, Raj JD. To assess the knowledge and attitude towards forensic odontology among dentists in Chennai city. Int J Forensic Odontol 2016;1:17-20.

16. Available from: http://www.iafo.in. [Last accessed on 2020 Jan 26].

17. Dany SS, Rajput P. Tangade P. Perception and awareness among dental professionals of Odisha towards forensic odontology. IJCPHR 2016;1:18-21.

18. Hannah R, Ramani P, Natesan A, Sherlin HJ, Gheena S, Ramasubramanian A, et al. Evaluation of knowledge, 
attitude and practice of forensic odontology among undergraduate dental students. Int J Orofac Biol 2017;1:16-20.

19. Bhakhri S, Kaur A, Singh K, Puri MS, Puri N, et al. Perception of forensic odontology and its practice among the local dentists of an institution. J Forensic Res 2017;8:377.

20. Rahman J, Routray S, Mishra SS, Mohanty I, Mohanty N, Sukla N. Knowledge, awareness, and practice of forensic odontology among dental surgeons in Bhubaneswar, India. J Unexplored Med Data 2017;2:26-33.

21. Rubel M. Prashant GM, Kumar PGN, Sushanth VH, Imranulla M, Mallick S, Potila I. Awareness and compliance about forensic odontology among dentists in dental colleges of Davangere City, Karnataka, India. Int J Biomed Res 2017;8:143-7.

22. Rudraswamy S, Doggalli N, Chandrashekar BR, Manjunath $\mathrm{M}$, Sreeshyla HS. Forensic odontology acquaintance among the students of a dental institution in Mysore City, India. Int J Forensic Odontol 2017;2:13-7.

23. Narayanan D, Radhakrishna P, Prabhu S, Jose M. The current status of forensic odontology in India: Perception of postgraduates, faculty members, interns and general dental practitioners. Int J Res Health Allied Sci 2017;3:42-5.

24. Shetty P, Raviprakash A. Forensic odontology in India, an oral pathologist's perspective. J Forensic Dent Sci 2011;3:23-6.
25. Kumaraswamy J, Nagarajachar RB, Keshavaiah R, Susainathan A, Sreenivas Reddy MB, Naidu J. A cross-sectional study to assess knowledge, attitude, and awareness of forensic odontology among medical students: An emergency concern. Int J Forensic Odontol 2018;3:17-20.

26. Roy M, Akhil S, Kumar RV, Thomas J, Saji AM, Iype AK. Connecting forensic odontology among medical practitioners in central Kerala-An original study. J Family Med Prim Care 2019;8:1427-31.

27. Selvajothi P, Lavanya C, Joshua E, Rao UK, Ranganathan K. Awareness of Forensic Odontology among Legal Professionals, Chennai, India. N Am J Med Sci 2014;6:553-7.

28. Pandit S, Desai D, Jeergal P, Venkatesh S. Awareness of forensic odontology among police personnel: A new ray of hope in forensic odontology. J Forensic Dent Sci 2016;8:56.

29. Sultan S. Awareness of forensic odontology \& child abuse among lawyers of Srinagar, India. IOSR J Dent Med Sci 2017;16:70-4.

30. Sharma D, Koshy G, Pabla A, Garg S, Singh M. An insight into the awareness and utilization of "dental evidence" among the police force in Punjab. J Forensic Dent Sci 2018;10:27-33.
How to cite this article: Pillai JP, Rambhia S, Chokkalingam TS and Asaithambi B. Awareness of forensic odontology among dental students, academicians, and dental practitioners in Gujarat: A questionnaire-based, cross-sectional study. J Forensic Dent Sci 2020;12(1):10-22.

\begin{tabular}{|l|c|}
\hline \multicolumn{2}{|c|}{ Access this article online } \\
\hline \multirow{3}{*}{ Website: } & Quick Response Code \\
\cline { 2 - 2 } www.jfds.org & \\
& \\
& \\
&
\end{tabular}

